\title{
Lexis in Political Ideas on Twitter
}

\author{
Renugah Ramanathan ${ }^{1}$, Tan Bee Hoon ${ }^{2}$, Shamala Paramasivam ${ }^{1 *}$ \\ ${ }^{1}$ Department of English, Faculty of Modern Languages and Communication, Universiti Putra Malaysia, Malaysia \\ ${ }^{2}$ Faculty of Social Sciences \& Liberal Arts, UCSI University, Kuala Lumpur, Malaysia
}

Corresponding Author: Shamala Paramasivam, E-mail: shamala@upm.edu.my

\section{ARTICLE INFO}

\section{Article history}

Received: June 16, 2017

Accepted: August 24, 2017

Published: December 01, 2017

Volume: 6 Issue: 7

Special Issue on Language \& Literature Advance access: September 2017

Conflicts of interest: Non Funding: None

\begin{abstract}
Ideologies in political discourse have been keen research topics as they provide various views of an issue or event. The prominent aspect of ideology is that it attempts to bridge the political activism to the social world that reflects the authenticity of political fi ures. This study aims to compare the ideological notions in the political tweets of Prime Minister Najib Tun Razak (henceforth, Najib) and Prime Minister Narendra Modi (henceforth, Modi) during the election campaigns. The discourse between both the political premiers are compared in relation to their active participation on Twitter in Asia. Data were collected over a period of 3 months during the election campaigns of both the countries which were from February to April 2013 in Malaysia and January to March 2014 in India. The study follows the qualitative research design by employing Fairclough's three dimensional model in analyzing the lexical choices and the formation of ideas. The presence of various ideologies in the tweets portray the consensual power of the political leaders as the citizens accepts the former's principles, ideologies and moral values. Hence, this study is significant because the study increases political awareness among citizens and provides insights on how language is employed by both leaders from different political coalition. Besides, this study produces knowledge that helps society to understand how 140 character can be a powerful tool in disseminating ideas during national elections and making election a success.
\end{abstract}

Key words: CDA, Ideologies, Power, Twitter

\section{INTRODUCTION}

The decision-making process in a nation heavily relies on its citizens and the election campaign. The previous elections in Malaysia were held on the $5^{\text {th }}$ of May 2013 while in India the elections were held from $7^{\text {th }}$ April to $12^{\text {th }}$ May 2014. The goal of an election is to legislatively elect a leader to run a country as well as to instill political knowledge among its citizens. In 2013, the electoral campaigns in Malaysia involved 15 political parties, where the two major political coalitions which included the current government, Barisan Nasional (henceforth, BN) and the opposition coalition, Pakatan Rakyat (henceforth, PR) contested vigorously (Moniruzzaman, 2013). BN is one of the largest leading political coalitions in Malaysia which was founded in 1973 and presently is a reputable party in Malaysia. In contrast to the electoral body in Malaysia, India is renowned for its multi-political party system as the number of political parties varies each year. The multi-political party system in India was formed after India gained independence in 1947. Regardless of the multi-political parties in India, the Bharatiya Janarta Party (henceforth, $\mathrm{BJP}$ ) is one of the leading parties in India to date and this party is one of the largest participating parties in 2014. BJP represents the people in India and this party adheres to the concept of integration between citizens in India, which is in line to the concept of BN.

Election campaigns have been frequently regarded as a democratic process whereby elected political candidates represent citizens in various aspects. Taking this notion into consideration, an election campaign is a dais where various ideas and concepts of political fi ures are disseminated to the citizens in order to achieve their motive in ruling a nation. Primarily, political notions are a significant aspect in election campaigns over the world and their ideas are widespread via conversations through various communicative channels such as mainstream media and social media such as Twitter. Twitter is a microblog introduced in 2006 and its concept is based on posting and retweeting tweets not exceeding 140 characters (Murthy, 2011; Bruns, 2012; Boyd, Golder \& Lotan 2010; Conover, Ratkiewicz, Francisco, Gonçalves, Menczer \& Flammini, 2011; Tumasjan, Sprenger, Sandner, \& Welpe, 2010). Apparently, Twitter infiltrated the realm of politics on $30^{\text {th }}$ April 2007, when the administrative organizing staff managing the official Twitter account of the then President of The United States (henceforth, U.S), Barack Obama tweeted: "Thinking we are only one signature away from ending 
the war in Iraq (Obama, 2007, April 29)". Digital media is not a new phenomenon in political communication. In fact, politics made its first appearance on digital media during the mid-1990s in party websites and the first candidate to have a political website was Senator Dianne Feinstein from U.S in 1994. Twitter is a powerful communicative tool for the purpose of engaging with citizens during electoral campaigns, promoting the political party both locally and internationally and ultimately to improve the chances for success.

Although various studies have been done in the field of social media example, Facebook, there has been limited study focusing on political discourse in Twitter especially during election campaigns in Asia, hence this gap needs to be filled (Kushin \& Kitchener, 2009). The need to fill in the gap is to observe how the two renowned political leaders in Asia persuade citizens to make election campaigns successful. The manipulation of Twitter as a platform of communication is an issue that persist in the political domain. Political manipulation is often regarded as the portrayal of power which leads to the presence of ideologies. Hence, the purpose of this study is to find out how lexical choices plays a vital role in unravelling the hidden ideologies and scrutinize the presence of power in the political tweets of Najib and Modi throughout the election campaigns. The specific objective is to investigate and compare the power employed in the political discourse of both the premiers as how citizens are influenced to vote for both the leading parties are probed.

\section{CRITICAL DISCOURSE ANALYSIS (CDA)}

Critical Discourse Analysis (henceforth, CDA) is an interdisciplinary approach which is essential in arenas such as institutions, communities, political organizations, cultures among others. The CDA approach is considered to be one of the fundamental approaches in discourse analysis whereby its criticality enables language to be scrutinized to reveal obscure, hidden, opaque and implicit functions or notions of language such as ideology, power, dominance, inequality and hegemony (Van Dijk, 1993, Wodak \& Meyer, 2009, Simpson \& Mayr, 2010, Fairclough, 1989). In relation to this approach, Van Dijk (1993) along with Simpson and Mayr (2010) both argue that CDA places its ultimate priority on the "social and ideological functions of language in producing, reproducing or changing social structures, relations and identities" (p.50). In this manner, it is apparent that CDA attempts to unravel and denaturalize covert ideologies that are embedded within the discourse. The following section will illustrate the representation of power, dominance and ideology in discourse.

\section{Power and Dominance}

Central to the concept of CDA, a prominent notion that is widely discussed in CDA is the subject of power and dominance. The idea of power has often been referred to the relationship between an individual and the institution whereby power is undoubtedly exercised. In relation to the domains of power, Fairclough (1989), Van Dijk (1995) Mills (2003) and Simpson and Mayr (2010) posit that power is somewhat a possession that belongs to an institution or a group of people as its sole purpose is to oppress and constrain the less powerful. However, Gramsci (1971) argues that apart from oppression and repression by the dominant group, power is regarded as a mechanism that is employed by the dominant group in persuading the powerless group to accept the power-holder's moral values, political beliefs and culture also known as (henceforth, a.k.a) hegemony. In regards to the notion of power by Gramsci (1999), power occurs between the power-holder and the powerless on the basis of active consent between both parties (Fairclough \& Wodak, 1997; Simpson \& Mayr, 2010). Similar to the notion of Fairclough (1989), Van Dijk (1995) Mills (2003) and Simpson and Mayr (2010), Van Dijk (1996) focus on social power in an organization or an institution rather than on individual dominance. According to Van Dijk (1996), social power refers to the form of control which is exercised by a group of people while constraining the absolute freedom or actions through the influence of knowledge, ideologies and attitudes upon the subordinate group. In the domain of politics, power is constantly referred to political actors who distribute power to specific social dominant groups who play an active role in suppressing others. The presence of power in the social domain leads to the manifestation of social dominance which legitimizes control over the interest of the powerless (Van Dijk, 1996). The use of dominance in democratic countries or societies often supports "persuasion and manipulation" (Van Dijk, 1996, p.85) rather than emphasizing on absolute force directly towards the powerless. Hence, it is perceived that power and dominance correlates as it abuses, accesses and empowers the society.

\section{Ideology in Discourse}

Ideology has its roots in many studies such as literature, filmolog, philology and cultural studies. The term ideology was introduced by a French philosopher Destutt de Tracy about 200 years ago. Later, Karl Marx adopted this discipline into the Marxist approach, which was closely bound into the field of sociology. According to Marx and Engels (1970), the notion of ideology refers to the pure interest of an idea (Susser, 1995) which is best understood as a mental missile between 2 people. Besides, Marx disclosed that when ideologies brawl in an unexpected circumstance, it is best to venture deeply into the ideology to unveil the implicit meaning which underlies the ideology. Another concept of Marx in ideology is the emergence of false consciousness (Susser, 1995). Marx perceived that there is a harmonious relationship between interest and ideas in which at the time, there is a tendency for an ideology to be distorted by one's own interest. In some cases, a person's ideology may become hostile to oneself. Since the $19^{\text {th }}$ century, the concept of ideology has been critiqued and modified according to the changes in our society. Presently, the term ideology has been addressed in various grounds differently in order to suit the studies or issues which are being researched. An influential ideologist in the field of language, Van Dijk (1998, 2006b) defines ideology as a fundamental property in which ideology has formed its roots. Ideology has been elucidated as the 
basic belief system or sets of ideas (Van Dijk, 1998, 2000, 2002a, 2006a) which are commonly shared by followers of a social group. The basic belief systems of an ideology are not merely the attitudes, social knowledge or worldviews in which a person possesses, but it is holistically both a mental and social phenomenon (Van Dijk, 1998).

Furthermore, Van Dijk (2006b) proclaims ideology into 4 properties in which ideologies are collectively owned by a group of people in a society that shares similar knowledge, consensus, culture and values. Hence, a social actor is not credited to a private or personal ideology. Secondly, ideologies are socially shared beliefs as they fundamentally dominate other sub-social beliefs. Thus, a feminist ideology may govern issues such as abortion, single mothers, social equality and women's rights. Thirdly, socio-cognitive foundations play a pivotal role as ideologies undergo gradual processes before it can be fully acquired by a person. For instance, a person is unable to be a racist or feminist overnight or change one's basic belief within a nick of time. Gaining an ideology involves experience and knowledge which can be often obtained from followers of a particular social group. Finally, an ideology may be terminated or it may no longer be applicable to a group of people. In such a case, group members may gradually disintegrate from an existing ideology or observe a new ideology according to one's interest. However, the term ideology is given a different view by a modern ideologist. Susser (1995) argues about three key points of a modern ideology; a) an ideology is comprised of bitter debates between various political parties competing on modern world-views b) ideology involves counter-discourse of contradictory views through critiques and valid arguments c) a modern ideology allows the construction of a conventional ideology to be reconstructed in a different manner (p.62).

A domain of society where ideologies are rife is the domain of politics. It is conventional that ideologies in politics comprises of major political ideas such as socialism, communism, liberalism, pragmatism and green politics. A political ideology is a set of ideas, principles, myths, or symbols of a particular social movement which manipulates the society. Van Dijk (2002b) defines political ideology as a dais where a "politicians" multiple ideological identities are enacted'. However, many political scientists are reluctant to accept the notion of ideology in social practice as social actors may observe numerous ideologies at once. Referring to this view, a social actor may be a feminist speaking on womens' rights in society but also a strong believer of conservatism or racism.

Ideologies in political discourse have simultaneously expressed the propositions and notions of political fi ures through speeches in various domains such as media, blogs, microblogs and social networking sites. In recent years, studies have focused on political speeches by prominent leaders portraying the concept of national integrity and unity policies. Horvath (2009) as well as Basser and Alvi (2011) have both examine the ideologies in President Barack Obama's inaugural speech. The analysis showed that, throughout the inaugural speech, a prominent ideology that had been depicted is ethnic diversity and unity. The particular emphasis on unity was made in relation to the ongoing war between the U.S. and Al-Qaeda that has affected U.S. citizens and weakened the current economy. Therefore, President Obama had acknowledged the strong citizenry despite the present state of the country. Akin to the concept of unity, Alo (2012) along with David and Dumanig (2011) highlight the idea of nationalism through a variety of lexical markers which were employed during the speeches of world premieres. The ideological stance that was discovered through lexical choices such as we, our and us conveyed that ethnic diversity from various walks of life led to the formation of unity in a nation. It was emphasized that the success of a country resided solely on the harmony of the citizens as national transformation and globalization were bound to occur. This form of ideological notion asserted the positive representation of politicians as the concern of equality and unity were demonstrated.

Previous studies have primarily concentrated on critical phenomena, whereby power relation, dominance within a domain, inequality among races, genders, and social classes leads to the emergence of various ideologies. These ideologies play a significant role in disregarding others while portraying a positive image of them. Zhang (2014) investigates the political news in the contexts of America and Iraq in The New York Times, scrutinizing the discursivity of text, interaction patterns and social practice in unmasking the different ideological consumptions of the Bush administration and Saddam Hussein during the war that occurred in Iraq. Negative ideological notions in this context arose from the Bush administration and Saddam Hussein as their concepts rely mainly on destruction and distress. Bush's administration and Saddam Hussein constantly oppressed the Iraqis in various ways to promote power and control within the domain. Another study by Mayasari, Darmayanti, and Riyanto (2013) in the context of politics is associated with clichés between the government and the non-governmental bodies in the construction of an anti-corruption building in Indonesia. The government's rejection towards the building of an anti-corruption building portrayed a negative image of the regime as the government is believed to be involved in corruption, and thus various reasons were specified to eliminate the project. Meanwhile, the non-governmental body possessed a positive notion as it had taken measures to execute the project of an anti-corruption move. Therefore, the relationship between the aspects of language and social structure unpacked the differing ideological notions of both the parties.

In a parallel study, Behnam and Mahmoudy (2013) discover the political ideology in Iran's nuclear report through discourse structure. In determining the ideological structures, the presupposition concept was employed leading to a specific ideological structure. This can be depicted through the phrase: "The information provided by Iran has not been adequate" (Behnam and Mahmoudy 2013, p.2198). The phrase denotes a negative belief on Iran. Besides, another preference in which ideology can be determined is through repetitive words in the report such as undeclared, uncertainties, inconsistencies, and contamination. These words depict a destructive image for the country such as: a) Iran is trying to conceal information from the world view, and b) Iran is inconsistent in its nuclear program. Similarly, Jahedi and 
Abdullah (2012a, 2012b) analyse the political discourse of post-September 11 in The New York Times (TNYT) focusing on the discursive strategies and linguistic implications of Iran. The political supremacy of U.S. was reflected through the ideology of 'outcasting' the Islamic State of Iran based on the assumptions of violence and extremism which was supported by U.S. views. The ideology of outcasting portrayed a biased image towards the U.S. as TNYT adjusted its content in line to the U.S policy against Iran. The exemplification of Muslims in Iran has been represented with a negative implication such as them being terrorists, aggressive and fundamentalists in the discourse of TNYT. Likewise, Shukry (2013) investigates the ideological concepts of Mahathir's speeches on War on Terror following the September 11 attack on the World Trade Centre. The representation of Bush's administration and Mahathir supported the dichotomy of $u s$ versus them when Mahathir's speeches reproduced a negative discourse towards the Bush administration while attributing positivity of himself. The realization of negative ideologies portrayed them as selfish, exploitative and greedy whereas the construction of $u s$ exhibited glorification, an authoritative stance and success. Therefore, this form of representation reinforced the existing perception that Bush exercised violence and inhumanity towards the Islamic community.

The political power structure that is being held by the U.S. has influenced and affected the political organization of various countries including Iran and Iraq due to their dominance and sovereignty. The tendency of media such as TNYT is patent as it tried to generate prejudice and unbalanced discourse which supported U.S. views on Middle Eastern countries. In general, to legitimize and encourage U.S policies and views, TNYT acted as a mediator in highlighting unfavorable ideologies of Iran and Iraq. For example, the event where Iran offered to conduct a Dialogue With Respect with U.S was portrayed as a threat by the U.S. A negative ideology that was depicted through the discourse of President Obama was the concept of mistrust on Iran that was built over decades (Fathi \& Sanger, 2009). In line with the negative representation of Iran and Iraq, Ali and Khalid (2008) points out how western media distorted the image of Muslims through the representation of negative concepts against the Islamic community. In the view of the U.S., Islam had been labelled as accusative, provocative and offensive, in addition to the U.S. raising queries on Islamic doubts and intention of real Muslims. The negative representation of Islam portrayed that western media had dominated the Islamic domain and exhibited biasness towards the country's stability and honour. The establishment of an ideology has a significant impact on the nation and citizens when it is viewed or supported with a biased image especially in the western media. The reflection of an implicit notion remains obscure but it holds a great role in portraying power and domination towards the oppressed group. Gottschalk and Greenberg (2008) regard that the U.S. has greatly expressed an intense ideology towards the Islamic domain, which is termed as Islamophobia. Most U.S. citizens believed that Islam is associated with the tragedy of $9 / 11$ as it indicates violence, terrorism and bombing. These negative representations of Islam are defined as prejudice towards the Islamic countries whereby Muslim countries such as Indonesia, Malaysia, India and Bangladesh are not involved in the political violence as are other Middle Eastern countries. Akin to these studies, Alo and Ajewole-Orimogunje (2013) study the ideological representation of political fi ures in the context of media discourse. According to the analysis, the ideology of human rights had been portrayed to signify the conquering and trapping of civilization by the horrendous act of politicians. Therefore, the various ideologies depicted in these studies portray that ideologies in media are an approach to lure citizens to accept the superior's notion in succeeding in an event.

\section{METHOD}

This study employs the qualitative research method to analyse the various ideological consumptions that occurred on Twitter during the electoral campaigns of the two countries. The data that was analysed included tweets of PM Najib Razak and PM Narendra Modi which were collected throughout a period of three months. To accumulate the data, the archives of both the Prime Ministers' official Twitter accounts were accessed using the Patriot Journalist Network website (http://patriotjournalist.com/). Using both the Prime Ministers' official Twitter account names, data was obtained to be copied and pasted to files in a Microsoft Word format. Tweets that are inclusive of 140 characters were examined to discern ideologies and their hidden implications as each political entity tended to represent various philosophical notions.

\section{Research Design}

The study is purely a qualitative study that deals with the investigation of Najib and Modi as political premiers during their respective election campaigns. A virtual definition of qualitative research is engaged with the "broad interpretivist in the sense that it is concerned with how the social world is interpreted, understood, experienced, produced or constituted" (Mason, 2002, p.3; Creswell, 2003). Besides that, qualitative research enables researches to form knowledge based on constructivist perspectives which comprises of authentic issues emerging from understanding the knowledge of the world (Creswell, 2003). Qualitative research focuses specifically on the formation of words as it exclusively governs the process of description and explanation in texts which are rich in meaning (Miles \& Huberman, 1994; Bryman, 2008).

\section{Data Collection Procedure}

The first step in gathering data for this study was to search for websites that enables previous tweets to be collected based on the preferred duration. One such website that permits tweets to be gathered is the Patriot Journalist Network (http://patriotjournalist.com/) website. This website was created by a team of conservatives to support societal issues 
that were discussed on Twitter. The Patriot Journalist Network was chosen as a means to collect data because it offers the facilities to search for previous tweets based on various search criteria which are embedded on Twitter. The common search criteria that could be used to retrieve prior data on Twitter is by using the Metadata Tag \# (Hashtag), Specific Words, Exact Phrases, Tweets To the sender, Time frame in searching for specific tweets and@Tweets From a particular individual. Another motive of employing this website to collect data is based on the accuracy of relevant results which are generated by this website.

The search criteria that was employed to collect the data was the '@Tweets From a particular individual' category. In this category, the Twitter account name of an individual is placed in the search bar, for instance@narendramodi or @NajibRazak, accompanied by the exact date which is set in the time frame locator. Upon completing the required search criteria with the specified date, the search is then ready to be executed on a two-separate basis for each of the political fi ures.

The search duration that was set for Modi was January 2014 while for Najib it was for February 2013. The subsequent tweets for the following months are automatically produced by the website whereby tweets for the duration of three months for both Modi and Najib were gathered. A total of 592 tweets were collected from the official profile of Najib and 545 tweets were gathered from the officia profile of Modi. Thus, the total number of tweets which was gathered was 1137 tweets. Apart from collecting tweets, it was important to keep the data organized, documented and guarded against loss and therefore, the data was collected and stored into a central document in the Microsoft Word format.

As the data was stored into a central Microsoft Word document, it then went through a process of examination and refinement. After reading and examining the tweets, refinement of the specified data was achieved by excluding tweets that were posted in Malay and Hindi languages. The exclusion of tweets included 413 tweets in Malay and 10 tweets in Hindi. The exclusion process was necessary as the main concern of this study is to analyze tweets that were originally posted in English only. Furthermore, the translation process of Malay and Hindi tweets to English was prevented due to the fact that translated phrases and sentences had the tendency to lose their exact meaning, in addition to reproducing ungrammatical sentences and word choices that vary, resulting in impreciseness. Moreover, the refinement process was conducted to achieve the objective of this study without disregarding other aspects in this study. Hence, a total of 714 tweets are analyzed in this study.

\section{Data Analysis Method}

This study employs the three-dimensional model in discourse analysis by Fairclough (1992) to illustrate the relationship between text, discursive practices and social practices. Figure 1 indicates Fairclough's three-dimensional model.

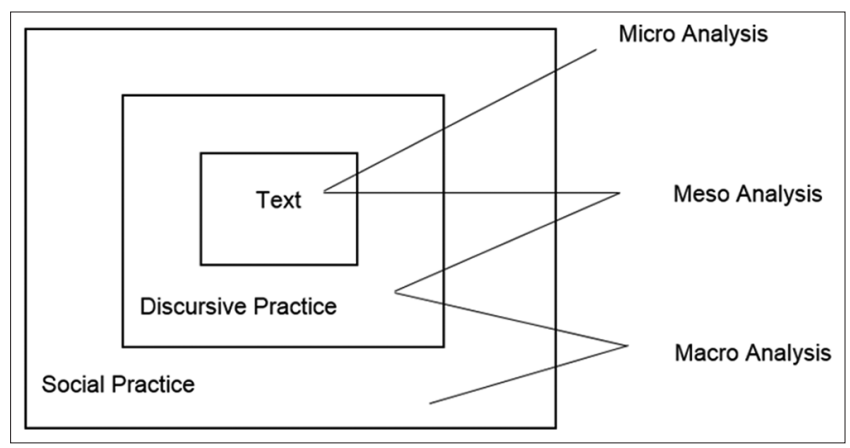

Figure 1. Fairclough's three-dimensional framework

\section{Text Analysis}

The first dimension in Fairclough's micro framework of critical discourse analysis is the textual analysis. Textual analysis covers various forms of linguistic analysis ranging from semantic vocabulary to the sound system (phonology). Fairclough classifies textual analysis as a linguistic analysis as this term provides an overall view of the entire textual analysis (Fairclough, 1995). Textual analysis is widely used in qualitative studies, particularly in content analysis. Textual analysis enables researches to perform extensive examinations of a particular text or content (Lockyer, 2008) in order to produce an interpretation or conclusion (McKee, 2003) of the text. Besides, textual analysis has the power to make a single text to represent the reality (McKee, 2003) from a structured perspective. Primarily, textual analysis is a basic technique used by researchers to analyse an author's mental mode (Carley, 1997) from various dimensions. A variety of textual analysis techniques are employed such as procedure mapping techniques, protocol analysis, and cognitive mapping techniques among others. In this study, texts which are in the form of tweets are analysed using the Word Frequency Query technique (WFQ) or the filtering technique (Carley, 1997). The WFQ technique produces a list of words including the frequency of each word. This which will enable ideologies to be formed through words that are regularly used. Meanwhile, the least frequent words are discarded.

\section{Discursive Practice}

Discursive practice mediates the relationship between a text and social practice whereby the text is "both constitutive and constituted" (Jorgensen and Phillips, 2002, p. 61). Through discursive practices, the text reflects and reshapes the social structures as it indirectly influences the society. Discursive practices should be viewed as dialectical as it reflects the deeper reality of the social force in discourse. Traditionally, a discursive practice involves the specific process of production, distribution and consumption of text, whereby various forms of identity, relation and ideas are depicted through this function of discourse (Fairclough, 1992; Simpson and Mayr, 2010). By means of intertextuality, the research highlights various ideologies during the election campaigns of both political leaders while engaging with the aspects of elections. Intertextuality reveals the different forms of voices and texts in representing major parts of the electoral campaigns and 
responses to the different types of word choices employed in the tweets of both political leaders.

E.g.: BJP believes in peace, unity, brotherhood \& Sadbhavana. We assure people of UP a developed \& riot free Uttar Pradesh.

The lexical choices such as peace, unity and brotherhood in the tweet engages the citizens and the nation in a harmonious relationship. The intertextuality that occurs between lexical choices highlights the concept of integrity. Hence, the ideological expression of integrity is revealed in this aspect.

\section{Social Practice}

Being the third dimension in Fairclough's three-dimensional model, social practice investigates the various ways in which discourse is associated with social phenomenon. The reality of discourse in the social context affects the behaviour of tweets during the elections taking into consideration factors surrounding the election campaigns (Fairclough, 1992; 1995). Social practice constitutes orientations such as politics, economics, social, cultural and ideological variations, hence this dimension enables discourse to view these scopes from a boarder perspective (Jorgensen and Phillips, 2002). The abstractness of social practice enables multiple embodiments of discourse to be integrated while representing the mental mode of a social actor or event (Van Dijk, 1995; 2009). In the tweets of Najib and Modi, ideologies which have been developed are interpreted according to the relevance of the election campaign.

Example of ideology: Better National for Better Nation

Najib's idea towards the notion of BN for better nation is committed in empowering the society while promising a better country.

\section{RESULTS AND DISCUSSION}

This section presents the results of the analysis in the tweets posted by Najib and Modi in relation to the general elections. The formation of ideologies is often considered abstract as principles and beliefs tend to reflect the social movements of political fi ures or social groups. Fundamental to the ideological notions, lexicalization plays a major role on the value of words in developing specific ideological stances. In this section, lexicalization contributes to the formation of ideologies in the tweets of Najib and Modi. Moreover, this section aims to identify the various forms of ideologies in the tweets of Najib and Modi which portray their beliefs and ideas during the national elections. Hence, the emerging lexical choices are highlighted in the formation of ideologies. Following the identified lexical choices, an appropriate interpretation is provided in relation to the dominant lexical choices which denotes the ideological frame. After the first and second step in Fairclough's three-dimensional model, the ideologies are weaved into the social practice stage which provides a broader view of the idea in relation to the social and historical context. This section highlights the various types of lexical units employed in the tweets of Najib and Modi. The salient lex- ical units found in the tweets were extracted to form ideologies which portrayed the ultimate idea of the election campaigns in Malaysia and India.

\section{Results in the tweets of Najib}

Idea 1: Notion of Barisan National for Better Nation

\begin{tabular}{l}
\hline Lexical choices \\
\hline Pledge \\
Initiative \\
Strive \\
Promises \\
Ease \\
\hline
\end{tabular}

Idea 2: The Concept of National Unity and Integrity (1 Malaysia)

\begin{tabular}{l}
\hline Lexical choices \\
\hline Together \\
Unity and diversity \\
Community \\
\hline
\end{tabular}

Idea 3: Notion of Social Media Elections 2013

\begin{tabular}{l}
\hline Lexical choices \\
\hline Share \\
Follow \\
Social media \\
\hline
\end{tabular}

Idea 4: Preserving Democratic Consensus among Malaysian during the 2013 elections

\begin{tabular}{l}
\hline Lexical choices \\
\hline Fundamental rights \\
Freedom \\
Healthy manner \\
\hline
\end{tabular}

\section{Results in the Tweets of Modi}

Idea 5: Concept of BJP as Human Integrity Party

\begin{tabular}{l}
\hline Lexical choices \\
\hline Peace \\
Unity \\
Brotherhood \\
\hline
\end{tabular}

Idea 6: Technological Elections during the 2014 general elections

\begin{tabular}{l}
\hline Lexical choices \\
\hline Integration of technology \\
Empower volunteers \\
India $272+$ mobile app \\
\hline
\end{tabular}


Idea 7: Revamping the nation's economic sector

\begin{tabular}{l}
\hline Lexical choices \\
\hline Economic \\
Must change \\
Rampant mismanagement \\
\hline
\end{tabular}

Idea 8: Emphasis on the virtues of democratic republic politics

\begin{tabular}{l}
\hline Lexical choices \\
\hline Democracy \\
Vote \\
Voting rights \\
\hline
\end{tabular}

\section{Discussion}

The ideologies in the tweets of Najib and Modi are comprises of eight ideological notions in total. The presence of ideas in the tweets of Najib contain four ideologies, which are a) The notion that Barisan National is for a Better Nation, b) The Concept of National Unity and Integrity (1 Malaysia) c) The notion of Social Media Elections 2013 and d) Preserving the Democratic Consensus among Malaysian during the 2013 elections. Meanwhile, the presence of ideologies in the tweets of Modi involves four distinct ideologies which are a) The concept of BJP as a Human Integrity Party, b) Technological Elections during the 2014 general elections, c) Revamping the nation's economic sector and d) Emphasis on the virtues of democratic politics. The notion of ideologies is prominent in various aspects of discourse and is often portrayed across an array of text and talk. However, in Twitter, the misinterpretation of the lexical choices during the election campaign is caused by the exhibition of limited word choices (140 characters). The negligence of ideologies is an acute issue to the citizens due to the limited word choices which has caused misapprehension and the revelation of obscure notions. Thus, this study explores the emerging ideologies in the tweets of Najib and Modi during the national elections.

The general elections in Malaysia highlighted on the notion of Barisan Nasional for a Better Nation through several lexical units. The word 'pledge' presents the support of citizens in the 2013 elections and this shows the citizens' commitment towards BN. The word 'strive' employed in the tweets of Najib portrayed Najib's intention in gaining the support of the Indian community for the benefit of the country. Moreover, Najib had stressed that he has since in his effort helped the Indian community to fulfil their needs in various aspects. In addition, the lexical unit 'initiative' enforced that Najib has undertaken measures in gaining the trust of the people while fulfilling the concept of Rakyat Didahulukan (People Come First). The word 'promises' in his tweets are enticing, which in turn displayed the manifestation of kept promises. In this concept, the manifestation of the three ethnic groups is being kept. Moreover, Najib has helped to ease the burden of the citizens in various aspects by providing initiatives in regards to the necessities of the citizens. The word 'ease' exhibited that Najib has assured to provide Prima housing to ease future home owners, Bantuan Rakyat 1 Malaysia, Clinic 1 Malaysia and the 1 Malaysia convenience store. The appearance of this ideology in the tweets of Najib during the 2013 national elections indicated an organized political system which solidified the perception of nation building. Najib's idea towards the notion of Barisan Nasional for a Better Nation has ignited an empowering of the society while promising a better country. As Najib heads the ruling party, it is significant to note that Najib has intensified this concept by endorsing to ease the cost of living, providing affordable houses, nurturing youths, strengthening women's participation and more. The findings of this study are in line with the notion of Van Dijk (1996) who asserts that domination on the powerless indirectly manipulates and persuades the thoughts and behaviour of citizens. Through persuasion, these ideologies are utilized as baits to lure citizens into casting their votes. Therefore, the concept of hegemony is exercised as the power holder succeeded in convincing the citizens during the national elections.

The idea of National Unity and Integrity (1 Malaysia) in Malaysia was used during the general elections in 2013. The result indicates that prominent lexical choices which were employed in the tweets of Najib portraying the concept of unity and integrity are the lexical units such as 'together' which symbolizes the harmonious relationship and understanding among people in a society especially during elections. The result shows that the lexis diversity and unity denotes the various ethnicities and religions in Malaysia, in which the acceptance and inclusion of all the races within the Malaysian society are acknowledged equally. Another lexical choice presented in the result is the word 'community'. This word asserts the equality of Malaysian citizens under the hood of 1 Malaysia during the election campaign. The concept of National Unity and Integrity which is embraced during the election campaign restores and maintains government's policies to prevent undesirable issues blooming during the elections. Moreover, the formation of this concept enables a leader with calibre to be chosen through the harmonious consent of the citizens. This ideology brings history to light when a tragedy took place in Malaysia on $13^{\text {th }}$ May 1969, which is known as a major riot between the three major ethic groups during the 1969 general elections. This tragedy claimed the lives of many innocent people and it has scarred a black mark in Malaysian history until this day. The implication of this riot in 1969 has resulted in the implementation of the idea of Unity and Integrity. Hence, Najib has taken measures to unite the three major races in Malaysia as this promoted a successful election campaign, in addition to preventing a possible bloodshed. As a whole, Unity and Integrity adds strength to the leadership of Najib as this has provided the opportunity for Najib and to engage with the public in order to gain the citizens' trust, support and vote for the upcoming elections (see fi ure 2 for example).

The first idea that emerged in the tweets of Modi is the notion of BJP as a Human Integrity Party. The dominant lexical units that emerged in Modi's tweets are words such 
as 'peace', 'unity' and 'brotherhood'. The results reveals that the word 'peace' in a democratic country such as India portrays an image of India that is free from violence, bloodshed, fear and war. Peace has led to unity which exhibits the notion of integration among people in India, whereby the state of being one is achieved. Besides, the result exhibits the presence of unity which has bound the citizens in being one brotherhood which defines the warmth, equality, creed and ethnicity within one nationhood. This concept promotes BJP's concept of cultural nationalism that places the people of India at center stage while emphasizing the principles of humanity. The philosophical objective of mankind that was highlighted by a prominent BJP leader Deendayal Upadhyaya is that 'body, mind, intellect and soul' correspond in achieving universal civilization (Philosophy of Bharatiya Janarta Party, 2016). The claim by Deendayal Upadhyaya strongly corresponds to the exact notion of Gandhi who believed in humanity and integrity. In line with the notion of both the notable leaders, Modi has continued this tradition by fostering the notion that BJP is indeed responsible for human integrity, unity and solidarity in India during the national elections. The emergence of this notion during the national elections in India is to unite the diverse races and ethnicities before the national elections. The presence of this ideology enhances a riot free election and maintains stability.

The concepts of National Unity and Integrity (1 Malaysia) and BJP as Human Integrity Party aligns with the fin ings of past studies by David and Dumaning (2011), Horvath (2009), Alo (2012), Basser and Alvi (2011) who stated that the success of a leader relies merely through the harmonious bond and unity between the leader and his citizens. Besides, countries that foster a pleasant relationship among citizens enable the government to recover from crisis in various aspects. Unity in Malaysia and India is extremely essential as political parties work together towards an achievable aim. Hence, the concept of unity in both the countries portrayed the concept of togetherness of the political parties and the citizens.

Another salient idea which has been highlighted during the elections in Malaysia is the Notion of Social Media Elections 2013. The result displays the concept which derived from lexical units such as 'share' which denotes the concept of contributing to the society through the use of technology. In this manner, the word 'share' enforces the ways in which Najib disseminated information in regards to the national

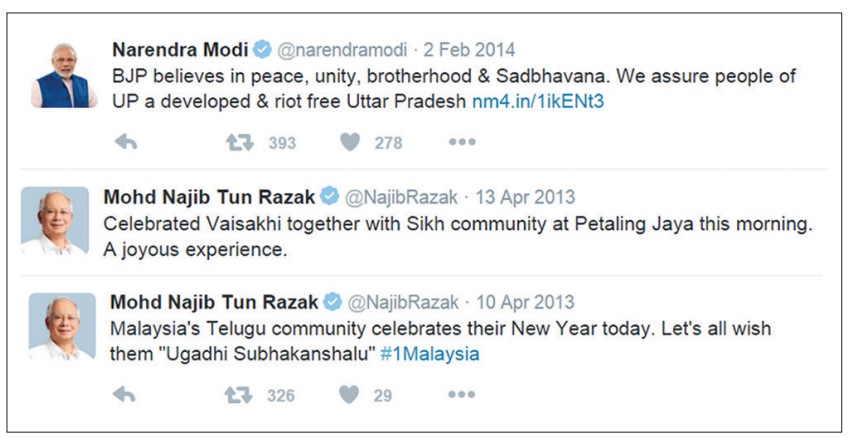

Figure 2. Concept of Unity and Integrity elections and future plans to the citizens via Twitter. Besides, the results exhibited another lexical unit which was the word 'follow'. The lexical choice 'follow' during the national elections implies that citizens are urged to trail and keep track of the latest news posted on Twitter. Besides, microblogs such as Twitter is one of the convenient applications which enables the citizens to follow Najib's latest updates. 'Social media' was another common lexical unit engaged in Najib's results. This lexical choice implies the notion of social media elections in which Malaysia's $13^{\text {th }}$ general elections is Malaysia's first social media elections. Bearing these lexical choices in mind, the formation of the notion of Social Media Elections 2013 has gained popularity during the elections whereby citizens have been constantly accessing Twitter to keep up with the latest updates.

The concept of Technological Elections during the 2014 General Elections in India was a salient ideology during the national elections. The results indicates that in this ideology, prominent lexical choices that portrays this notion is 'mobile app'. The employment of this lexical unit portrays that Modi has used technology to empower volunteers in contributing to the election campaign. Besides, the use of technology has created a network between the citizens and the politicians which is employed to persuade voters into casting their votes for BJP. The lexical choice 'integration of technology' based on the result shows that citizens constantly contributed to the development of India's 2014 election campaigns via the use of technology. Being active participants of social media, the Modi campaign has kept the ball rolling throughout the elections by constantly posting tweets on Twitter and other social media platforms regarding events, campaigns, objectives and strategies as well as other information that is deemed beneficial and for the citizens post-election (see fi ure 3).

The usage of social media and technology in the elections is to entice netizens to vote for the BN and BJP parties and to dominate the entire social media electoral campaign. The power and domination of Modi and Najib throughout the technological electoral campaigns is consistent with the literature by Fairclough $(1989,2003)$ as well as Wodak and Meyer (2009), who mentioned that ideologies reflect certain aspect of the world as it establishes, constructs and maintains power and dominance while manipulating the minds of the society through discourse structures. The notion of power and dominance influenced the dominant group (political leaders) mainly as it enabled the construction of ideologies to be akin to their thoughts. Based on this ideological notion, Modi and Najib as power holders manipulated and dominat-

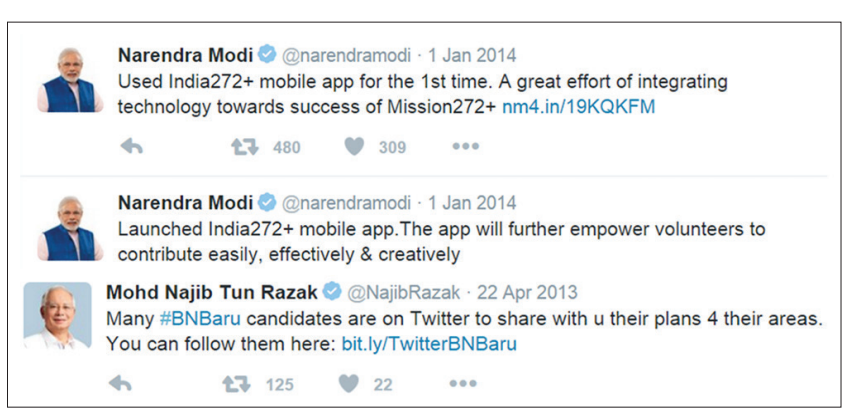

Figure 3. Enhancing the use of technology during elections 
ed the minds of netizens by enforcing the usage of technology throughout their campaigns in order to gain success.

Revamping the economic sector in India presents another prominent notion in the tweets of Modi. The results shows that the occurrence of this ideology is apparent through lexical choices such as 'rampant mismanagement', which portrays the economic sector in India has been deteriorating due to corruption, lack of concern of the ruling party and the misuse of power in the economic sector. In relation to these issues, Modi has stressed on the weakening economic sector in India in order to reform the current condition. In addition, the results exhibits the words 'must change' which expressed Modi's concern towards the primary and secondary economic sector rather than tertiary economic sector. The change from the tertiary sector to the primary and secondary sectors has been emphasized as investments in the agriculture sector which will increase the revenue of the country. In relation to the political situation in India, Modi's concern is to improve the political situation in order to enable the economics of India to progress. Thus, by strengthening India's political situation, the nation's economy will improve in the three sectors which are the primary, secondary and the tertiary economic sectors. This ideology is significant as this sheds light on the government's revenue for the public. As the national economy is declining in India, public support towards the government has decreased and this has caused major political clichés between political parties. Hence, in order to gain public support, Modi's tweets on national economic matters were to fortify the citizens' belief the political party.

The portrayal of the notion of Emphasising the Virtues of Democratic Republic Politics in the tweets of Modi asserted the participation and rights of voters during the 2014 general elections. The exhibition of this ideology is vivid through lexical choices such as 'voting rights' which had promoted various channels of voting for voters, especially through social media as internet-based campaigning was a novice in India's 2014 general elections. This has eased citizens to exercise their rights regardless of their presence during the national elections. In addition, the lexical choice vote shows that Modi is in the venture of conquering India through the emphasis of requesting the citizens to vote especially in states with high population. This significant idea of a democratic republic was evident as Modi urged citizens to vote for a presidential representative. In the concept of a democratic republic, the power to elect a president rests directly in the hands of the citizens. In India, the ultimate democratic republic principles which have been grounded since independence are the principles of sovereignty (an independent nation), socialism (providing social and economic equality to all Indian citizens), democractism (head of government is democratically elected by citizens) and secularism (the freedom to choose religions). These vital principles of a democratic republic in India is prominent throughout the election campaigns as India's democratic republic system is stagnant in multiple aspects (see fi ure 5). Before the Election Day (see fi ure 4).

A salient belief during the 2013 general elections in Malaysia is the notion of Preserving Democratic Consensus among Malaysians during the 2013 elections. Based on the results, the portrayal of the lexical unit 'fundamental rights' denotes that Najib guarantees citizens of numerous fundamental rights in which citizens are free from any form of oppression by the authorities. Moreover, the results exhibited that the word freedom is primarily related to the notion of democracy in Malaysia and one such practice is the rights to vote and the freedom of speech, religion and movement. The idea of voting is to elect the strongest party to rule the country and to portray the notion of a democratic country. Najib has granted equal rights to citizens in all aspects regardless of colour, caste, class and religion as well as emphasizing the principles of individual rights (see fi ure 6). Furthermore, the results portrays that the lexical unit healthy manner reflects the usage of language in an appropriate manner without causing slander during the elections. The exhibition of slander may result in legal to be action taken against the party by the political action committee. Hence, the concept of a healthy manner is to promote politeness and to enhance public spiritualness. Bearing this notion in mind, Najib inculcates the notion of democracy as a core belief throughout the electoral campaign. The highlighted notion provided absolute rights to the citizens' a.k.a individual freedom to elect party representatives who were able to protect human rights and govern the nation. Although Najib aimed for victory and success, yet it is apparent that Najib respects, supports and protects fundamental rights of citizens without violation.

The portrayal of ideas such as Revamping the economic sector in India, Preserving Democratic Consensus among Malaysian during the 2013 elections and Emphasising the Virtues of Democratic Republic Politics is in line with past studies by Gramsci (1971), who states that dominant groups constantly succeed in encouraging the lower social group to accept the former's political ideology as well as cultural and political values through active consent. In these concepts,

Narendra Modi @narendramodi.19 Jan 2014

Called for creating a globally recognised Brand India built on 5 Ts- Talent, Tradition, Tourism, Trade \& Technology nm4.in/1h4nLyg

Narendra Modi @ @narendramodi·15 Jan 2014

Pitiable condition of the economy must change. Time has come to set the agenda \& bring the country back on track $\mathrm{nm} 4$.in/1 1 coxgUo

$$
\text { ↔ 比 } 604 \vee 395 \quad \cdots
$$

Figure 4. Notion of revamping the economic sector

Narendra Modi @narendramodi.24 Mar 2014

$\mathrm{SC}$ order on giving voting rights to armed forces personnel at location of their posting is a welcome step \& will increase participation.

h $47954 \bigcirc 653 \quad \ldots$

Figure 5. Concept of emphasizing virtues of democratic republic

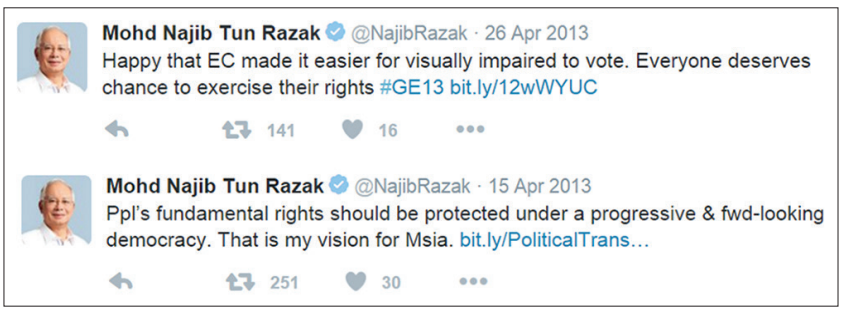

Figure 6. Notion of preserving democratic consensus 
Najib and Modi as dominant political fi ures conveyed their ideas while anticipating that these ideologies are embraced by the citizens in making the election a success. Hence, it is evident that Najib and Modi as dominant leader instilled these concepts upon the society.

In comparison to the notions of Najib and Modi, the presence of similar and contrasting ideologies are spotted in $\mathrm{Na}$ jib and Modis' tweets during the national elections. A similar ideological notion in the tweets of Najib and Modi is the concept of Technological Elections during the 2014 General Elections in India and Notion of Social Media Elections 2013 in Malaysia. The occurrence of this ideology in both the nations is due to the openness of social media, especially via microblogs in Malaysia and India. Microblog is employed as a platform to engage with citizens while disseminating information pervasively. In addition, BJP as a Human Integrity Party and National Unity and Integrity (1 Malaysia) exhibited a common ideology between both the leaders. The occurrence of this ideologies during the election campaigns enabled citizens to harmoniously participate in the electoral campaigns without causing riots and jeopardizing the reputation of the nation.

In the aspect of discourse, the ideologies are in line to the concept of power by consent. Gramsci, (1971) elucidates that power by consent is vivid during the national elections as citizens are influenced through persuasion of ideologies to accept Najib and Modi's belief, moral values and political norms. Citizens of the countries have accepted these ideologies because the ideologies present the governing institutions. Although Malaysia is governed by Democratic constituency and India is governed Democratic Republic constituency, the supreme power in electing calibre leader solely depends on the citizens as an entire population and citizens as individuals. Hence, the hegemonic power which is exercised by these constituencies is essential through discourse depicted in the election tweets. As a result of power by consent, the election campaigns were successful as Najib and Modi were voted to be the political representatives.

\section{CONCLUSION}

In relation to the literature, the microblog plays a significant role in the production of various ideologies that exhibit power of the dominant group. Previous studies in the domain of ideologies have been investigated in multiple aspects such as in media discourse studies and political discourse studies. However, there has been little research conducted on the investigation and comparison of discourse in Twitter between renowned political fi ures in Asia. The adoption of Fairclough's three-dimensional model portrayed the various types of lexical units employed in the tweets of Najib and Modi. Results revealed power by consent was employed in the tweets as Najib and Modi successfully persuaded the citizens to accept the former's belief and values therefore, the election campaigns were a success. This study is significant as political notions are revealed through discourse which is an eye-opener to citizens. Besides, this study creates an awareness of how Twitter has been employed as a powerful tool during national elections in Malaysia and India in disseminating information to the citizens via discourse. It is hoped that the current study contributes towards the importance of microblogs and discourse skewing the Twitter users perception towards the language used on Twitter.

\section{REFERENCES}

Ali, S., \& Khalid, M. (2008). US mass media and Muslim world: portrayal of Muslims by news-week and time. European Journal of Scientific Resea ch, 21(4), 554-580.

Alo, M. A. (2012). A Rhetorical Analysis of Selected Political Speeches of Prominent African Leaders. British Journal of Arts and Social Science, 10 (1), 87-100.

Alo, M., \& AJEWOLE-ORIMOGUNJE, C. O. (2013). Discourse Strategies and Ideology in Selected Radio Lead News of Osun State Broadcasting Corporation, Nigeria. 3L: The Southeast Asian Journal of English Language Studies, 19 (2), 111-123. http://journalarticle.ukm. my/6524/.

Basser, A., \& Alvi, S. D. (2011). An Analysis of Barack Obama's Speech 'Keynote Address at the 2004 Democratic National Convention'. Language in India, 10, 310-335.

Behnam, B. \& Mahmoudy, B. (2013). A critical discourse analysis of the reports issued by the International Atomic Energy Agency (IAEA) Director General on Iran's nuclear program during the last decade. Theory and Practice in Language Studies. 3(12), 2196-2201.

Boyd, D., Golder, S., \& Lotan, G. (2010). Tweet, tweet, retweet: Conversational aspects of retweeting on twitter. In Proceedings of the $43^{\text {rd }}$ Hawaii International Conference on System Science, 1-10.

Bruns, A. (2012). How long is a tweet? Mapping dynamic conversation networks on Twitter using Gawk and Gephi. Information, Communication \& Society, 15(9), 1323-1351.

Bryman, A. (2008). Social Research Methods. Oxford: Oxford University Press.

Carley, K. M. (1997). Extracting team mental models through textual analysis. Journal of Organizational Behavior, 533-558.

Conover, M., Ratkiewicz, J., Francisco, M., Gonçalves, B., Menczer, F., \& Flammini, A. (2011). Political Polarization on Twitter. In Proceedings of the Fifth International AAAI Conference on Weblogs and Social Media.

Creswell, J. W. (2003). Research Design: Qualitative, Quantitative, and Mix Methods Approaches ( $2^{\text {nd }}$ ed.). Thousand Oaks, California: Sage Publication.

David, M. K., \& Dumanig, F. P. (2011). National unity in multi-ethnic Malaysia: A critical discourse analysis of Tun Dr. Mahathir's political speeches. Language Discourse \&Society, 1(1), 11-31.

David, M., \& Dumanig, K. F. (2011). National unity in multi-ethnic Malaysia: A Critical discourse analysis of Tun Dr. Mahathir's political speeches. Language, Discourse and Society, 1(1), 11-31.

Fairclough, N. (1989). Language and Power. London: Routledge.

Fairclough, N. (1992). Discourse and Social Change (Vol. 73). Cambridge: Polity press. 
Fairclough, N. (1995a). Critical discourse analysis. The critical study of language. London: Longman.

Fairclough, N., \& Wodak, R. (1997). Critical Discourse Analysis. In T.A. Van Dijk (Eds). Discourse as Social Interaction. (pp. 258-284). London: Sage.

Fathi, N., \& Sanger, D. E. (2009). Iran Offers 'Dialogue with Respect'with US. New York Times.

Gottschalk, P., \& Greenberg, G. (2008). Islamophobia: making Muslims the enemy. USA: Rowman \& Littlefield

Gramsci, A. (1971). Selections from the Prison Notebooks. London: Elecbook.

Grusell, M., \& Nord, L. (2012). Three attitudes to 140 characters the use and views of twitter in political party communications in Sweden. Public Communication Review, 2(2), 48-61.

Horváth, J. (2009). Critical discourse analysis of Obama's political discourse. In Proceedings of Language, literature and culture in a changing transatlantic world, International conference, University of Presov, 45-56.

Jahedi, M., \& Abdullah, F. S. (2012a). Post-September 11 discourse: The case of Iran in The New York Times. International Journal of English Linguistics, 2(1), 59-70.

Jahedi, M., \& Abdullah, F. S. (2012b). The ideological construction of Iran in The NYT. Australian Journal of Linguistics, 32(3), 361-381.

Jorgensen, M. W., \& Phillips, L. J. (2002). Discourse analysis as theory and method. London. Sage.

Kushin, M. J., \& Kitchener, K. (2009). Getting political on social network sites: Exploring online political discourse on Facebook. Peer-Reviewed Journal on the Internet, 14(11).

Lockyer, S. (2008). Textual Analysis. In Lisa M. Given (Eds.), The Sage Encyclopedia of Qualitative Research Methods. (pp. 865-867). Thousand Oaks, CA: Sage Doi: http://dx.doi.org/10.4135/9781412963909.n449.

Marx, K., \& Engels, F. (1970). The German Ideology. New York, NY: International Publisher.

Mason, J. (2002). Qualitative Researching (2 ${ }^{\text {nd }}$ ed.). London: Sage Publication.

Mayasari, M., Darmayanti, N. \& Riyanto, S. (2013). Critical discourse analysis of reporting on" Saweran for KPK Building" in media Indonesia Daily Newspaper. International Journal of Linguistics. 5(4), 213-224.

McKee, A. (2003). Textual Analysis: A Beginner's Guide. London: Sage.

Miles, M. B., \& Huberman, A. M. (1994). Qualitative Data Analysis: An Expanded Sourcebook. Thousand Oaks, California: Sage Publication.

Mills, S. (2003). Michel Foucault. London: Routledge.

Moniruzzaman, M. (2013). The $13^{\text {th }}$ Malaysian general election: Uncertainties and expectations. Intellectual Discourse, 21(1), 55.

Murthy, D. (2011). Twitter: Microphone for the masses? Media Culture and Society, 33(5), 779-789.

Obama, B. (2007, April, 29). Thinking we're only one signature away from ending the war in Iraq. Learn more at http://www.barackobama.com (tweet). Retrieved from: https://witter.com/barackobama/status/44240662?lang=en.
Philosophy of Bharatiya Janarta Party (2016). Integral Humanism. Retrieved from: http://www.bjp.org/about-theparty/philosophy/?u=integral-humanism.

Puschmann, C. (2015). The form and function of quoting in digital media. Discourse, context and media. 7, 28-36.

Shukry, A. S. M. (2013). A critical discourse analysis of Mahathir Mohamad's speeches on the "war on terror". Intellectual Discourse, 21(2), 171-195.

Simpson, P., \& Mayr, A. (2010). Language and Power: A Resource Book for Students. Oxon: Routledge.

Susser, B. (1995). Political Ideology in the Modern World. Boston: Allyn \& Bacon.

Tumasjan, A., Sprenger, T. O., Sandner, P. G., \& Welpe, I. M. (2010). Predicting Elections with Twitter: What 140 Characters Reveal about Political Sentiment. In Proceedings of the Fourth International AAAI Conference on Weblogs and Social Media,178-185.

Van Dijk, T. A. (1993). Principles of Critical Discourse Analysis. Discourse \& Society, 4(2), 249- 283.

Van Dijk, T. A. (1995). Power and the news media. In D. Paletz (Ed.). Political Communication and Action (pp. 9-36). Cresskill, NJ: Hampton Press

Van Dijk, T. A. (1996). Discourse, power and access. In C. R. Caldas-Coulthard \& M. Coulthard (Eds.). Texts and Practices. Readings in Critical Discourse Analysis. (pp. 84-104). London: Routledge.

Van Dijk, T. A. (1998). Opinions and Ideologies. In A. Bell \& P. Garrett (Eds.), Approaches to Media Discourse. (pp. 21-63). Oxford: Blackwell.

Van Dijk, T. A. (2000). Ideology and Discourse: A multidisciplinary Introduction. Barcelona: Pompeu Fabra University.

Van Dijk, T. A. (2002a). Political Discourse and Ideology. In C. U. Lorda \& M. Ribas (Eds.), Analysis of Political Discourse. (pp. 15-34). Barcelona: Pompeu Fabra University.

Van Dijk, T. A. (2002b). Discourse and Racism. In D. Goldberg \& J. Solomos (Eds.), The Blackwell Companion to Racial and Ethnic Studies. (pp. 145-159). Oxford: Blackwell.

Van Dijk, T. A. (2003). Critical discourse analysis. In D. Tannen, D. Schiffrin \& H. Hamilton (Eds.), Handbook of discourse analysis. (pp. 352-371). Oxford: Blackwell.

Van Dijk, T. A. (2006a). Ideology and Discourse Analysis. Journal of Political Ideologies, 11(2), 115-140.

Van Dijk, T. A. (2006b). Politics, Ideology and Discourse. In K. Brown (Eds.), Encyclopedia of Language and Linguistics ( $2^{\text {nd }}$ ed.) (pp. 728-740). Boston: Elsevier.

Van Dijk, T. A. (2009). Critical discourse studies: A sociocognitive approach. In R. Wodak \& M. Meyer (Eds). Methods of critical discourse analysis ( $2^{\text {nd }}$ ed.) (pp 6286). Thousand Oaks: Sage.

Wodak, R., \& Meyer, M. (2009). Critical Discourse Analysis: history, agenda, theory and methodology. In R. Wodak \& M. Meyer (Eds). Methods of critical discourse analysis (2 ${ }^{\text {nd }}$ ed.) (pp 1-33). Thousand Oaks: Sage.

Zhang, M. (2014). A critical discourse analysis of political news reports. Theory and Practice in Language Studies, 4(11), 2273-2277. 